\section{Dirty money}

The fossil-fuel divestment campaign raises important questions but offers few solutions.

A global campaign to persuade organizations to sell their shares in fossil-fuel firms is gathering momentum. The divestment movement argues that universities and other institutions should not even tacitly support the companies that sell the products responsible for greenhouse gases. It is a moral argument that carries particular weight with universities, which have helped to spell out the dangers of emissions, but one that fails as a serious strategy for tackling climate change.

These are complex issues, as demonstrated by recent conflicting decisions at three universities that have considered divestment. As we report on page 16, SOAS University of London announced on 24 April that it would give up all of its fossil-fuel investments in the next three years. Six days later, the New York University (NYU) senate adopted a resolution calling on the university to maintain its investments in some 200 companies that deal in fossil fuels, but to develop a greener investment strategy for the future. The resolution sought to prevent further investment in fossil fuels, but said that divestment of existing investments would reduce returns from the university's US\$3.4-billion endowment. And on 2 May, Swarthmore College in Pennsylvania announced that it would create an alternative fund that is free of fossil-fuel investments, instead of relinquishing investments from its existing endowment.

A report by an NYU senate committee says that $\$ 139.7$ million $4.1 \%$ of the school's endowment - is invested in the 200 fossil-fuel companies of concern. But just $\$ 700,000$ falls under the direct control of the university's fund managers. The rest is invested through external brokers who typically purchase shares in funds with a broad portfolio of assets. As a consequence, divesting the $\$ 139$ million would mean selling off and reinvesting shares worth $\$ 1.3$ billion. It could be done, but the committee unanimously recommended that the senate hold on to these investments.

NYU is hardly unique. Just about anybody who has a retirement account or owns shares in a mutual fund is likely to find themselves in the same situation. And even if they do not, fossil fuels have a role in pretty much every facet of their daily lives, from the electricity that they use to the food they eat, the home they live in and the transportation they take to work - bicycles and public transport included.
"Even advocates of divestment admit that the main purpose is to raise awareness." Divestment is a complicated affair, and avoiding the worldly benefits that fossil fuels offer to citizens in developed countries is downright impossible.

So far, at least 28 universities have taken a stand against fossil fuels, but the benefits of institutional divestment are not clear. Universities that sell their shares in fossil-fuel companies must find buyers, so the most that they can hope to achieve is to push down the stock price a little. But the world still runs on fossil fuels, and until a better option arises, the current business model will surely continue. Furthermore, where would the universities put the cash that they have freed up through divestment? Extra investment is always welcome, but it is not at all clear that the relatively small clean-energy sector could absorb a cash infusion of the scale under discussion here.

In the end, even advocates of divestment admit that the main purpose of the campaign is to raise awareness. The movement is a by-product of the fact that governments have been slow to act, and frustration is understandable. The question is how to harness that angry energy without further polarizing the debate. This is a collective problem, and vilifying the fossil-fuel industry merely displaces blame.

The real challenge is to bolster the science and implement effective public policies that will drive all investments in the right direction. Fossil-fuel companies must play their part, and those that do not may ultimately succumb to a new generation of energy companies. All investors will need to negotiate this transition, which comes with both risks and huge opportunities. But the primary role of universities, irrespective of how they choose to invest their endowments, is to conduct research, inform public policy and educate the leaders of the future.

\section{Greek cash grab}

\section{Government's decision to plunder university funds shows lack of respect for science.}

\section{$\mathrm{T}$} he appointment of physicist Costas Fotakis as Greek science minister had some researchers hoping that the incoming government, led by Alexis Tsipras, was determined to save Greek science from the vortex of the country's debt crisis. Some hope. The dominant mood among the nation's scientists now is outrage at new measures that raid research funds in a bid to stave off financial collapse. A decree approved on 24 April forces Greek universities and research centres to transfer any cash reserves they still hold to the Greek central bank.

Faced with horrendous capital flight from Greece, the government intends to use the funds - money that research organizations have set aside to pay electricity bills and other overhead costs not covered by external grants - to meet pressing financial obligations to international creditors.

Athens's high-handed grip on disposable university budgets is unlikely to generate any substantial revenue. Instead, the ill-conceived move threatens to rekindle Greek scientists' long-held aversion to the state. To balance the books, many observers point out, Greece would be better taking aim at the long-standing problem of poor tax compliance.
The government has assured outraged university rectors that the measure is temporary, and that universities can expect to get their money back without losses. And in the worst case - if Greece were to default on its loans and had to leave the eurozone - money deposited at private banks would be more at risk than deposits with the Bank of Greece, says Fotakis.

That may be so. But handing over research money to a government that has yet to prove its fiscal competence comes with a risk of its own. And with massive budget cuts over the past five years, Greek science has already paid its fair share towards solving the debt crisis.

The decree is not the only problem. A controversial bill proposed last month would reverse some of the reforms introduced by the previous government to bring Greece's science and higher-education system in line with European norms. The government should be wary of changes that clash with attempts to make Greek universities more attractive to foreign students and scientists.

With a research expenditure of less than $0.6 \%$ of gross domestic product, Greece is one of the least science-friendly countries in Europe. Strengthening science is essential to stimulate economic growth and create the jobs that Greece so urgently needs.

If the government takes science seriously - and Fotakis's appointment was a signal that it does - it should scrap the idea of borrowing $\rightarrow$ NATURE.COM To comment online, click on Editorials at: go.nature.com/xhunqv money from cash-strapped research organizations. Political farsightedness and respect for science - a profession of truly Greek origin - demand that the detrimental decree be reversed.. 